\section{Raised Beds and Metalaxyl for Controlling Phytophthora Root Rot of Raspberry}

\author{
K.E. Maloney ${ }^{1}$ W.F. Wilcox ${ }^{2}$, and J.C. Sanford ${ }^{1,3}$ \\ Cornell University, New York State Agricultural Experiment Station, \\ Geneva, NY 14456
}

Additional index words. integrated pest management, IPM, Phytophthora fragariae var. rubi, Phytophthora erythroseptica, Phytophthora megasperma, Rubus idaeus

\begin{abstract}
Titan' red raspberry (Rubis idaeus L.), highly susceptible to root rot caused by Phytophthora fragariae Hickman var. rubi Wilcox \& Duncan (syns. P. erythroseptica Pethyb., "highly pathogenic" P. megasperma Drechs.), was planted in June 1990 in a silt loam naturally infested with the pathogen. Raked beds $(0.36 \mathrm{~m}$ high) dramatically reduced disease incidence and severity relative to flatbed treatments. In contrast, metalaxyl at 372 $\mathrm{mg} \cdot \mathrm{m}^{-1}$ of row provided little benefit when applied to flat beds and provided consistently moderate but statistically insignificant effects when applied to raised beds. Relative to the flat bed system, primocane vigor was increased in 1992 by $16 \%, 190 \%$, and $224 \%$ in the flat bed plus metalaxyl, raised bed, and raised bed plus metalaxyl treatments, respectively; total yields were increased by $7 \%, 231 \%$, and $272 \%$ with these same respective treatment. The results indicate that raised-bed planting systems can provide substantial control of phytophthora root rot of red raspberries even when highly susceptible varieties are grown on otherwise marginal sites. Metalaxyl appears more effective as a supplement rather than substitute for raised beds under such conditions. Chemical name used: $N$ - $(2,6-$ dimethylphenyl) $-N$ - (methoxyacetyl)alanine methyl ester (metalaxyl).
\end{abstract}

During the 1980s, phytophthora root rot became recognized as a major cause of declining red raspberry plantings in commercial production areas worldwide. A general program has been proposed for controlling the disease (Wilcox, 1991)—one that integrates pathogen exclusion, site modifications to promote water drainage (e.g., raised-bed planting systems), use of partially resistant cultivars, and treatment with specific fungicides. However, this program's individual components are not equally practical or desirable. For instance, many raspberry fields are now contaminated with pathogenic Phytophthora spp., precluding the possibility of pathogen exclusion when such sites are replanted. Furthermore, some cultivars, which are otherwise among the most profitable and horticulturally desirable, are also highly susceptible to the disease (Barritt et al., 1981; Wilcox and Nevill, 1992). Therefore, the purpose of this experiment was to examine the efficacies of a raisedbed planting system and registered fungicide treatment, both singly and in combination, when replanting a highly susceptible cultivar in a pathogen-infested site.

The experiment site, located near Geneva, N.Y., on Lima silt loam soil, was nearly level. A previous raspberry planting was removed from the site in 1989, following a prolonged

Received for publication 5 Apr. 1993. Accepted for publication 11 June 1993. The cost of publishing this paper was defrayed in part by the payment of page charges. Under postal regulations, this paper therefore must he hereby marked advertisement solely to indicate this fact.

${ }^{1}$ Dept. of Horticultural Sciences.

${ }^{2}$ Dept. of Plant Pathology.

${ }^{3}$ To whom reprint requests should be addressed. decline due to root rot associated with $P$. fragariae var. rubi, the primary Phytophthora species causing red raspberry root rot in North America and Europe. This pathogen has been referenced in the literature as $P$. erythroseptica (e.g., Bristow et al., 1988; Converse and Schwartze, 1968), a highly pathogenic variant of $P$. megasperma (e.g., Duncan et al., 1987), and $P$. fragariae (Wilcox, 1989). However, the conspecificity of isolates ascribed to all three taxa has been demonstrated, and the new tax on recently has been proposed (Wilcox et al., 1993).

In 1990, four treatments, flat and raised beds with and without metalaxyl, were established in a split-plot randomized complete block design with four replications. Individual raised beds were produced using a two-row culminated disk adjusted to provide one large bed, which was constructed of soil taken from the alleyways between it and the adjacent rows to either side. Although this ultimately caused a slight depression in the portions of the alleyways immediately abutting the beds, as evidenced by water puddling, there was no such discernible effect at the position of the adjacent rows. A back-blade attachment then was used to level and shape the beds and row middles, and beds were rolled to help maintain their shape and minimize settling. At the start of the experiment, raised beds were $1.4 \mathrm{~m}$ wide at the base, $910 \mathrm{~mm}$ wide at the top, and 360 $\mathrm{mm}$ high; beds were $320 \mathrm{~mm}$ high and widths were unchanged when the last data were collected 30 months later. The sides of the raised beds were covered with black plastic mulch to minimize erosion, weed growth, and water loss. Flat beds were not covered with plastic mulch and were conventional in all respects.
Dormant virus-indexed plants of the highly susceptible 'Titan' were obtained from a commercial nursery and planted in June 1990, in rows spaced $3.7 \mathrm{~m}$ apart, with $610 \mathrm{~mm}$ between plants in a row. Individual plots consisted of a single row, $11.6 \mathrm{~m}$ long. The fungicide metalaxyl (Ridomil 2E; CIBA-GEIGY Corp., Greensboro, N.C.) was applied to the soil in a band $\approx 900 \mathrm{~mm}$ wide centered on the row, at a rate of $372 \mathrm{mg} / \mathrm{linear}$ meter of row, using a single-nozzle, boom herbicide sprayer. Application dates were 5 Nov. 1990,4 Apr. and 8 Oct. 1991, and 7 Apr. 1992. Plants were supplied with (in $\mathrm{kg} \cdot \mathrm{ha}^{-1}$ ) $11215 \mathrm{~N}-15 \mathrm{P}-15 \mathrm{~K}$ fertilizer banded $25 \mathrm{~mm}$ beneath the soil surface in July 1990,224 $\mathrm{NH}_{4} \mathrm{NO}_{3}$ broadcast on the herbicide strip in Apr. 1991, and 448 20N20P-20K fertilizer similarly broadcast in Apr. 1992. Weeds were controlled with 6-chloro$N, N^{\prime}$-diethyl-1,3,5-triazine-2,4-diamine (simazine) and 4-(dipropylamino)-3,5-dinitrobenzenesulfonamide (oryzalin); insects with $O, O$ dimethyl $S$ - (4-oxo-1,2,3-benzotriazin-3(4 $H$ )yl)methyl phosphorodithioate (azinphos-methyl); and foliar and fruit diseases with calcium polysulfide, 3-(3,5-dichlorophenyl) $-\mathrm{N}$ ( 1 - methyle thy l) - 2,4-dioxo-1 imidazolidinecarboxamide (iprodione), and 3(3,5-dichlorophenyl)-5-ethenyl-5-methyl-2,4oxazolidinedione (vinclozolin), according to standard practices. Plants were unsupported during the 1990 and 1991 growing seasons, and were supported on a V-trellis during 1992. No cane thinning, tipping, or other such manipulations were employed.

Initial disease incidence was determined on 2 July 1991, based on the frequency of original mother plants dead or dying in each plot. Phytophthora root rot was confirmed by isolating $P$. fragariae var. rubi from a sample of symptomatic plants on modified PARPH selective medium (Wilcox, 1989). During 1991 and 1992, determination of disease severity was based on berry production and primocane growth. Each October, the number of healthy primocanes was counted in the center $6 \mathrm{~m}$ of the row in each plot; the diameters of these canes (or a 50-cane subsample) were measured $250 \mathrm{~mm}$ above the soil line with a caliper and converted to cane cross-sectional area. Yields were measured by picking all berries from each plot area throughout the harvest season and were expressed as cumulative seasonal weights. Yields from 1992 also were used to estimate the mean seasonal mass of fruit per cane by converting the density of healthy primocanes determined in Oct. 1991 to an equivalent density of fruiting canes in the entire plot the following year. Average berry weight was determined on each harvest date in 1992 and for two harvest dates in 1991 by dividing the weight of a $470-\mathrm{cm}^{3}$ sample by the number of berries in the sample, and the seasonal mean was computed. Yield data were analyzed using the SAS general linear models . procedure (SAS, 1989), and treatment means were separated by Duncan's multiple range test; primocane and disease incidence data were analyzed using standard analysis of variance and the Wailer-Duncan $k$ ratio $t$ test variable for mean separation. 
Minor changes in the planting site grade were associated with variable levels of disease development among replicate plots of individual treatments. Although characteristic of the pattern of phytophthora root rot development under field conditions (Wilcox, 199 1), this variability appeared to diminish the statistical significance of large differences among some treatment means. Nevertheless, relative to the conventional flat bed system (control), the raised bed system had a pronounced effect on reducing the incidence of initial plant mortality and increasing primocane vigor. In contrast, metalaxyl provided only modest and statistically insignificant $(P \leq 0.05)$ improvements in plant survival and vigor compared with the nontreated plots of each planting bed system (Table 1). For instance, relative to the control treatment, cane cross-sectional areas in the flat bed plus metalaxyl, raised bed, and raised bed plus metalaxyl treatments were increased by $9 \%, 50 \%$, and $55 \%$ in 1991, and by $-2 \%, 45 \%$, and $52 \%$ in 1992 , respectively. When a weighted vigor measurement of healthy primocanes was determined for each plot in 1992 by multiplying the average cross-sectional area times cane density, mean increases relative to the control treatment were $16 \%$, $190 \%$, and 224\%, respectively (Table 1).

Yield components were similarly influenced by these various treatments. Yields were low during the first fruiting year due to incomplete stand establishment; no treatment was statistically superior to the control $(P \leq 0.05)$, although the yield of the raised bed plus metalaxyl treatment was more than double that of the control (Table 2). Differences among treatments were dramatic by the second fruiting year, when yields in the raised bed and raised bed plus metalaxyl treatments were increased by $231 \%$ and $272 \%$ relative to the control, respectively; in contrast, metalaxyl provided virtually no increase in yield when applied to the flatbed system (Table 2). Yield increases in 1992 were associated with differences in cane productivity, e.g., the grams of fruit per cane in the raised bed plus metalaxyl treatment was more than triple that in the control treatment (Table 2). In 1991, mean berry weights were similar in both of the raised bed treatments and significantly greater $(P \leq$ $0.05)$ than those in both flatbed treatments. In contrast, berry weights were slightly lower in the raised than in the flat beds in 1992 (Table $2)$; although not statistically significant $(P \leq$ 0.05 ), these differences are consistent with the greater fruit load per cane in the raised bed treatments.

These data demonstrate that a raised bed planting system can allow commercial levels of production of even highly susceptible raspberry cultivars, such as 'Titan', when they are replanted at a site previously supporting injurious levels of phytophthora root rot. Raised bed systems also might aid control of fungal diseases of the fruit, canes, and foliage by favoring air circulation and drying within plant canopies. Disadvantages of such systems include equipment needs, bed construction costs, increased irrigation needs, and altered weed management practices. In our experiment, black plastic mulch controlled weeds on the sides of the beds, maintained structural integrity of the beds, and reduced moisture loss. Although it was effective, the plastic often was tom by mowing equipment and was not durable enough for long-term use. New landscape fabrics may provide the same benefits, yet be easier to work with and of greater longevity than black plastic.

Significant production and dissemination of zoospores, the primary infective propagule of Phytophthora spp., are virtually dependent on saturated soil conditions. For instance, relative to saturated conditions, the number of zoospores of $P$. cryptogea Pethyb. \& Laff. and $P$. megasperma was reduced by $\approx 65 \%$ in soil with a water tension of $0.5 \mathrm{kPa}$ and by $90 \%$ in soil with a tension of $1.0 \mathrm{kPa}$; zoospores were undetectable at a tension of $2.5 \mathrm{kPa}$ (MacDonald and Duniway, 1978). By definition, these are the equilibrium tensions that would exist in the soil of a raised bed at heights of 50,100, and $250 \mathrm{~mm}$ above a layer of standing water, respectively (Griffin, 1972). Furthermore, motility of $P$. cryptogea zoospores was reduced significantly relative to that in saturated soil when tensions were maintained at 0.1 and $1.0 \mathrm{kPa}$, and motility was not detected through a soil mix with a water tension of $5.0 \mathrm{kPa}$ (Duniway, 1976).

Therefore, the reduction in disease severity provided by the raised bed treatments in our experiment likely was due largely to the provision of a rooting zone in which soil water tensions generally exceeded those supportive of significant zoospore activity. Similarly, root and crown rots caused by $P$. cryptogea, $P$. drechsleri Tucker, and P. megasperma were insignificant when mahaleb cherry (Prunus mahaleb L.) seedlings were maintained under controlled conditions with soil water tensions $\geq 1.0 \mathrm{kPa}$, although they were severe if the same soils were periodically saturated (Wilcox and Mircetich, 1985). It is uncertain to what degree Phytophthora mycelium can grow through infected roots within a saturated zone into tissue beyond that zone, e.g., from root segments extending beneath a raised bed into those in the drier soil above, but this ability apparently was limited under the conditions of the present study.

Although metalaxyl provided poor control of root rot in the flat bed system, it has provided much better results in other trials (e.g. Bristow, 1980; W.F.W., unpublished data) and in widespread commercial usage (W.F.W., personal observations). Apparently, the limitations of the fungicide were exceeded under the conditions of this experiment by a combination of host susceptibility, inoculum availability, environment, and soil drainage characteristics. In contrast, however, the combination of metalaxyl plus raised beds provided optimal results for all measures of disease incidence and seventy, even though increases in vigor and yield relative to raised beds alone were never statistically significant. The statistical uncertainty of these results notwithstanding, metalaxyl would be an economically advantageous component of an integrated control program when used in addition to raised beds, should it actually provide the moderate yield increases experienced in this trial. (For example, the increase of $1070 \mathrm{~kg} \cdot \mathrm{ha}^{-1}$ associated with such an addition in 1992 was obtained at a product cost of about $\$ 340 / \mathrm{ha}$, calculated on the basis of two seasonal applications and a cost of $\$ 38 /$ liter for Ridomil 2E.)

Table 1. Influence of raised beds and metalaxyl on initial plant mortality and growth and vigor of subsequent primocanes of 'Titan' red raspberries planted in 1990 into soil naturally infested with Phytophthora fragariae var. rubi.

\begin{tabular}{|c|c|c|c|c|c|c|}
\hline \multirow[b]{4}{*}{ Treatment } & \multicolumn{6}{|c|}{ Primocane growth and vigor ${ }^{2}$} \\
\hline & \multicolumn{3}{|c|}{ Canes } & \multirow{2}{*}{\multicolumn{2}{|c|}{$\begin{array}{c}\text { Cross-sectional } \\
\text { area }\left(\mathrm{mm}^{2}\right) \\
\end{array}$}} & \multirow{3}{*}{$\begin{array}{c}\text { Vigor } \\
\text { index }^{\mathrm{x}} \\
\text { Oct. } 1992\end{array}$} \\
\hline & \multirow{2}{*}{$\begin{array}{l}\text { Dead (\%) } \\
\text { July } 1991\end{array}$} & \multicolumn{2}{|c|}{ Healthy (no.) ${ }^{y}$} & & & \\
\hline & & $\overline{\text { Oct. } 1991}$ & Oct. 1992 & Oct. 1991 & Oct. 1992 & \\
\hline Flat bed (control) & $33 \mathrm{a}$ & $18 \mathrm{a}$ & $67 a$ & $44 \mathrm{~b}$ & $101 \mathrm{~b}$ & $68 \mathrm{~b}$ \\
\hline Flat bed plus metalaxyl ${ }^{w}$ & $34 \mathrm{a}$ & $18 \mathrm{a}$ & $80 a$ & $48 \mathrm{~b}$ & $99 \mathrm{~b}$ & $80 \mathrm{ab}$ \\
\hline Raised bed & $9 \mathrm{~b}$ & $25 \mathrm{a}$ & $135 \mathrm{a}$ & $66 a$ & $146 \mathrm{a}$ & $197 \mathbf{a b}$ \\
\hline Raised bed plus metalaxylw & $4 \mathrm{~b}$ & $25 \mathrm{a}$ & $143 \mathrm{a}$ & $68 \mathrm{a}$ & 154 a & 221 a \\
\hline
\end{tabular}

${ }^{2}$ Mean values from four replicate plots per treatment. Mean separation within a column by the WallerDuncan Bayesian $k$ ratio LSD rule $(P \leq 0.05)$.

${ }^{y}$ Number in the center $6 \mathrm{~m}$ of row.

xPrimocane vigor index $=($ number of healthy canes per $6 \mathrm{~m}$ of row $) \times($ mean cross-sectional area $) / 100$. "Metalaxyl applied at a rate of $372 \mathrm{mg} /$ /inear meter of row in Nov. 1990, Apr. and Oct. 1991, and Apr. 1992

Table 2. Influence of raised beds and metalaxyl on yield components of 'Titan' red raspberries planted in 1990 into soil naturally infested with Phytophthora fragariae var. rubi.

\begin{tabular}{|c|c|c|c|c|c|c|c|}
\hline \multirow[b]{4}{*}{ Treatment } & \multicolumn{5}{|c|}{ Yield $^{2}$} & & \\
\hline & \multicolumn{2}{|c|}{1991} & \multicolumn{3}{|c|}{1992} & \multirow{2}{*}{\multicolumn{2}{|c|}{ Berry wt $(\mathrm{g})^{\mathrm{z}}$}} \\
\hline & & Percent & & Percent & & & \\
\hline & t.ha ${ }^{-1}$ & control & $\mathrm{t} \cdot \mathrm{ha}^{-1}$ & control & g/cane & 1991 & 1992 \\
\hline Flat bed (control) & $0.37 \mathrm{a}$ & 100 & $2.57 \mathrm{~b}$ & 100 & $307 b$ & $2.7 \mathrm{~b}$ & $4.7 \mathrm{a}$ \\
\hline Flat bed plus metalaxyly & $0.46 \mathrm{a}$ & 127 & $2.76 \mathrm{~b}$ & 107 & $350 \mathrm{~b}$ & $2.6 \mathrm{~b}$ & $5.0 \mathrm{a}$ \\
\hline Raised bed & $0.69 \mathrm{a}$ & 189 & $8.51 \mathrm{a}$ & 331 & $779 \mathrm{a}$ & $3.8 \mathrm{a}$ & $4.5 \mathrm{a}$ \\
\hline Raised bed plus metalaxyly & $0.85 \mathrm{a}$ & 232 & $9.58 \mathrm{a}$ & 372 & 955 a & $3.7 \mathbf{a}$ & $4.4 \mathrm{a}$ \\
\hline
\end{tabular}

${ }^{2}$ Mean values from four replicate plots per treatment. Mean separation within a column by Duncan's multiple range test $(P \leq 0.05)$.

${ }^{y}$ Metalaxyl applied at a rate of $372 \mathrm{mg} /$ linear meter of row in Nov. 1990, Apr. and Oct. 1991, and Apr. 1992. 
Nevertheless, our data clearly indicate that the raised bed planting system is the far more influential component of such a program. This single cultural practice provided a dramatic and significant increase in yield, and is particularly attractive considering that the modest costs likely to be associated with its establishment are depreciable over the life of the planting.

\section{Literature Cited}

Barritt, B.H., P.C. Crandall, and P.R. Bristow. 1981. Red raspberry clones resistant to root rot. Fruit Var. J. 35:60-62.

Bristow, P.R. 1980. Raspberry root rots in the Pacific Northwest. Acta Hort. 112:33-38.

Bristow, P.R., H.A. Daubeny, T.M. Sjulin, H.S Peppin, R. Netsby, and G.E. Windom. 1988. Breeding for root rot resistance in red raspberry.
J. Amer. Soc. Hort. Sci. 113:588-591.

Converse, R.H. and C.D. Schwartze. 1968. A root rot of red raspberry caused by Phytophthora erythroseptica. Phytopathology 58:56-59.

Duncan, J. M., D.M. Kennedy, and E. Seemüller. 1987. Identities and pathogenicities of Phytophthora spp. causing root rot of red raspberry. Plant Pathol. 36:276-289.

Duniway, J.M. 1976. Movement of zoospores of Phytophthora cryptogea in soils of various textures and matric potentials. Phytopathology 66:877-882.

Griffin, D.M. 1972. Ecology of soil fungi. Syracuse Univ. Press, Syracuse, N.Y.

MacDonald, J.D. and J.M. Duniway. 1978. Influence of the matric and osmotic components of water potential on zoospore discharge in Phytophthora. Phytopathology 68:751-757.

SAS. 1989. STAT user's guide. version 6. SAS Institute, Cary, N.C.

Wilcox, W.F. 1989. Identity, virulence, and isola- tion frequency of seven Phytophthora spp. causing root rot of red raspberry in New York. Phytopathology 79:93-101.

Wilcox, W.F. 1991. Phytophthora root rot, p. 34-36. In: M.A. Ellis, R.H. Converse, R.N. Williams, and B. Williamson (eds.). Compendium of raspberry and blackberry diseases and insects. Amer. Phytopathol, Soc., St. Paul, Minn.

Wilcox, W.F. and S.M. Mircetich. 1985. Influence of soil water matric potential on the development of phytophthora root and crown rots of Mahaleb cherry. Phytopathology 75:648-653.

Wilcox, W.F. and J.R. Nevill. 1992. Differential susceptibility of raspberry cultivars and selections to phytophthora root rot, 1991. Biol. Cult. Tests 7;5

Wilcox, W.F., P.H. Scott, P.B. Hamm, D.M Kennedy, J.M. Duncan, C.M. Brasier, and E.M. Hansen. 1993. Identity of a Phytophthora species attacking raspberry in Europe and North America. Mycol. Res. 97:817-831. 